\title{
General consideration of Pakshaghata and its management using natural medicine
}

\section{and Ayurveda principles}

Available online at www.ijistweb.com

\section{REVIEW ARTICLE}

Vd. Shankar Lahuraj Mane*1, Amol S. Patil ${ }^{2}$, Vd. Shital Shankar Mane ${ }^{3}$, Jagdish P. Patil ${ }^{4}$, Ajit U. Dahatonde $^{5}$

${ }^{1}$ HOD \& Reader of Dept. of Panchakarma, Rural Institute of Ayurved \& Research Centre \& Hospital, Mayani, Dist- Satara, India.

${ }^{2}$ HOD \& Asst Prof, Dept. Kaumarbhritya, Shri Gurudeo Ayurvedic College, Gurukunj Ashram, Mozari, Dist. Amravati, India.

${ }^{3}$ Lecturer, Dept of Rog Nidan Evum Vikriti Vigyan, Rural Institute of Ayurved \& Research Centre \& Hospital, Mayani, Dist-Satara, India.

${ }^{4}$ HOD and Asst Prof, Dept. of Panchakarma, Shri Gurudeo Ayurvedic College, Gurukunj Ashram Mozari, Amravati, Maharashtra, India.

${ }^{5}$ Asst. Prof., Dept. of Kaumarbhritya, Shri Dhanvantari Ayurveda College and Research Centre, Semri Mathura, UP, India.

*Corresponding Author's E-mail: shnkrmane@gmail.com

\begin{abstract}
Pakshaghata (Hemiplegia) is one of the most common causes of death especially in elder age group. Pakshaghata mainly occurs due to the obstruction of cerebral blood vessels, ischemia, and lack of glucose metabolism and weakness of nerve cell. Loss of movement, sensory deficit, dysarthria, atrophy, stiffness and disturbed nerve impulses are the major symptoms of disease. Ayurveda offers various treatment modalities for the management of Pakshaghata such as; use of herbs \& formulation, yoga and Shodhana Chikitsa. Present article described various approaches of ayurveda for the management of Pakshaghata including natural herbs and Shodhana Chikitsa.
\end{abstract}

Keywords: Ayurveda, Pakshaghata, Vatavyadhi, Hemiplegia, Herbs, Shodhana Chikitsa.

\section{Introduction}

Pakshaghata is a Vatavyadhi and large number of population affected by disease globally and elderly aged peoples are more susceptible than younger one. Various etiological factors such as; Virudha Aahara, Atijagarana, Ati Vyavaya, Asruk srava, Vichesta, Dhatu kshya, Shoka, Chinta, Diwaswapna, Marmabhighata and Vegasandharana initiates pathogenesis of Pakshaghata. Modern science described age, arteriosclerosis, injury, hemorrhage, nutrition imbalance and anxiety as causative factors of disease. These factors vitiated Doshas especially Vata, causes nerve degeneration further resulting obstruction in nerve impulse which lead to altered functioning of cerebral vessels and finally hemorrhagic strokes (1-5). The disease manifestation involve Sira Snayu Shoshatva, Shithiltva of Sandhibandhana, loss of movement especially one side of body, dysarthria, loss of sensory impulses, facial rigidity and disturbed muscular tone associated with altered nerve functioning (4-9).

\section{Ayurveda Management of Pakshaghata:}

Nidan Parivarjana, Shaman, Shodhana Chikitsa and use of natural medicines are the basic line of treatment suggested by traditional text of ayurveda for the management of disease. Ayurveda drugs like; Sariva and Manjishta remove vitiation of Rakta and help to maintain balances of Rakta dhatu thus offers Raktaprasadana effect in Pakshaghata. 
Drugs; Pippalyadi, Salasaradi, Surasadi gana dravyas, lekhaniya dashemani and chedaniya dravyas may help to remove clots associated with Pakshaghata. Drugs possessing Katu rasa offers Shonitasanghatabhedana property. Katu rasa dravyas also having ushna, tikshna and laghu gunas which helps to corrects digestive and metabolic functioning (agnideepana), these drugs possessing lekhana effect thus scrapes out accumulated Kapha and Medas. Herbs like; Elettaria cardamomum, Cinnamomum camphora, Valeriana wallichii, Saussurea lappa, Cissampelos pariera, Embelia ribes, Cedrus deodara, Piper longum, Plumbago zeylanica, Zingiber officinale, Haridra and Pongamia pinnata may be used in the management of Pakshaghata. Drugs are also prescribed for Avagharshana with Lavana and Thaila for external application while internal application of natural drugs help to dissolve obstruction/clot thus improves blood flow.

Kshara dravyas helps to remove obstruction in srotas, Ksharas of Nymphaea stellata, Nelumbo nucifera, Butea monosperma, Pterocarpus marsupium, Callicarpa macrophylla and Glycyrrhiza glabra with honey and ghee recommended in Pakshaghata to remove blood clots (7-10).

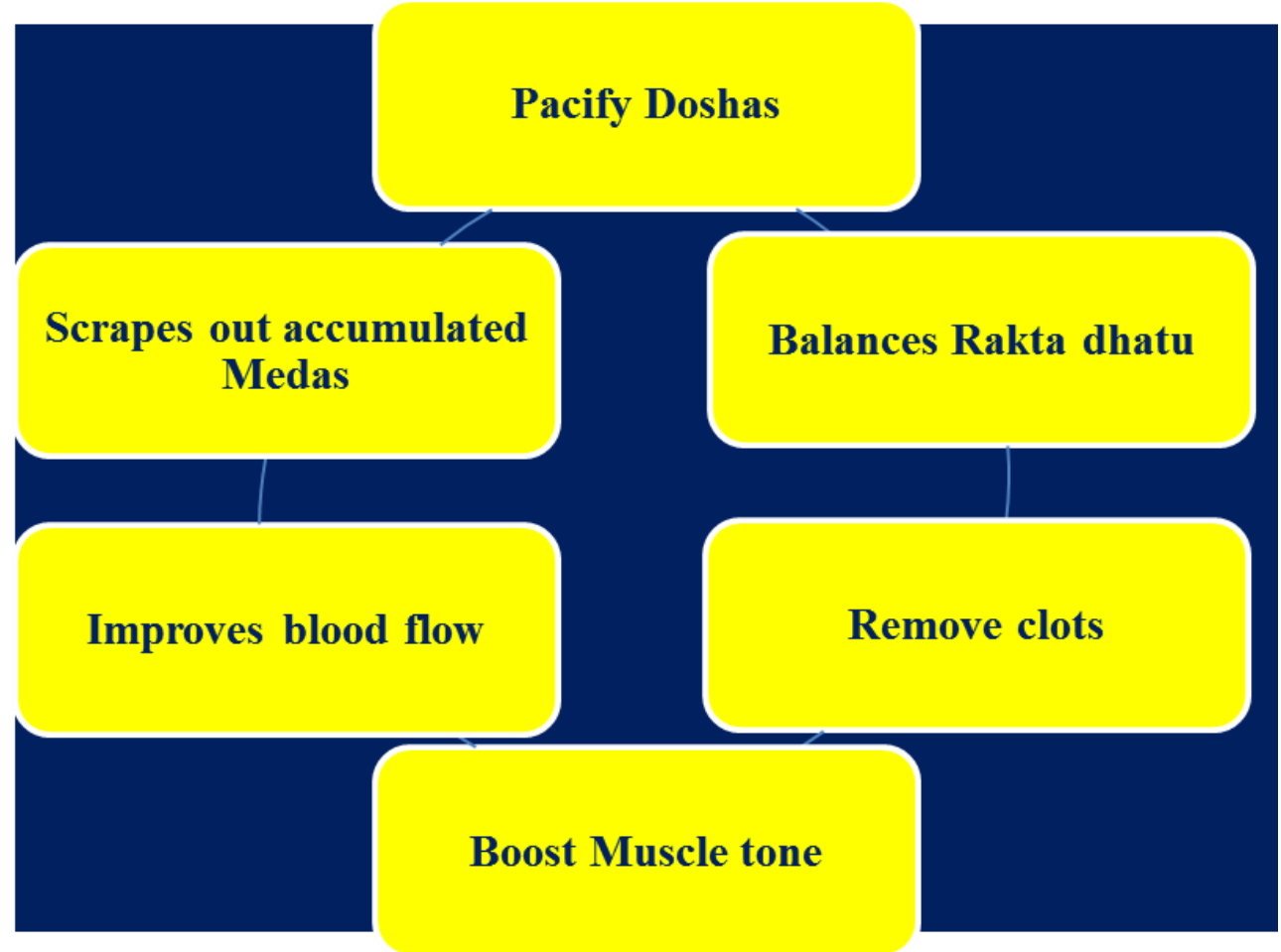

Figure 1: Beneficial eeffects of Ayurveda therapies in Pakshaghata.

Herbs which may be recommended in Pakshaghata are as follows:

- Madhuka (Glycyrrhiza glabra Linn)

- Sariva (Hemidesmus indicus R. Br.)

- Haridra (Curcuma longa Linn)

- Bhunimba (Andrographis paniculata Nees)

- Ananta (Fagonia arabica Linn.)

- Pippali (Piper longum Linn)

- Sunthi (Zingiber officinale Roscoe)

- Haritaki (Terminalia chebula Retz)

- Brahmi (Bacopa monnieri (Linn) Pennell)

Madhuka (Glycyrrhiza glabra Linn)
Glycyrrhiza glabra offers clot lysis activity due to the presence of Glycyrrhizin and Glycyrrhetic acid which possesses corticoid like activity. Glycyrrhiza glabra offers significant relief in predisposition factors of Pakshaghata such as; hypernatreamia, oedema and hypertension, etc.

\section{Sariva (Hemidesmus indicus)}

Sariva possess anti-oxidant and antithrombotic activity due to its ability to delayed plasma recalcification time. This herb also enhances release of lipoprotein lipase enzyme thus inhibits ADP induced platelets aggregation which sometime may lead initial symptoms of Pakshaghata. 


\section{Haridra (Curcuma longa Linn)}

Haridra having katu \& tikta rasa and ushna virya considered lekhaniya dashemani drug help to improve circulatory process and maintain normal functioning of heart. Haridra offers hypolipidaemic, antiatherosclerotic and antidiabetic effects thus prevent chances of Pakshaghata. It also having fibrinolytic \& thrombolytic effect therefore may be used for dissolving minor clot.

\section{Bhunimba (Andrographis paniculata Nees)}

Bhunimba having Tikta rasa, laghu ruksha guna and katuvipaka properties along with deepana and kaphapittahara effect. It possesses hypoglycemic, antioxidant and antihypertensive activities. These properties of herb offer beneficial effects in prevention of prognosis of early stage Pakshaghata. This herb also proved to have thrombolytic properties one of the major advantages in disease like Pakshaghata.

\section{Haritaki (Terminalia chebula Retz)}

Haritaki is considered Hridya, Medhya and Kaphavatahara. Haritaki is laghu \& ruksha ushna dravya possessing deepana, pachana and vibandhahara properties. Extracts of drug reported to have potent platelet aggregation inhibition activity thus may be recommended for the management of disease like; Pakshaghata.

\section{Brahmi (Bacopa monnieri (Linn) Pennell)}

Brahmi help to boost memory and combating stress, Brahmi is rasayana drug considered as Hridya, swarya and medhya. Brahmi having antioxidant, hypotensive, vasodilator and antidiabetic activities along with mental strengthen qualities. These all properties of Brahmi may be utilized effectively for the prevention and early stage management of Pakshaghata. This drug also reported to have significant clot lytic properties thus recommended in thrombosis.

\section{Pippali (Piper longum Linn)}

Pippali mitigates deranged Kapha vata, possess hypoglycemic and coronary vasodilatory effect. It also proven to have anticoagulant activity and significantly inhibits activities of thrombin aggregation factors. Therefore Pippali offer vital role towards the prevention of thrombosis associated with Pakshaghata.

\section{Sunthi (Zingiber officinale Roscoe)}

Sunthi classically offers kaphavatahara and pachana effect, it also exerted vibandhabhedana property thus help to breaks down vascular obstruction. Extracts of drug reported to have antioxidant, cardioprotective and hypocholesterolaemic activities thus may be used as preventive measure of Pakshaghata. Antiplatelet aggregation and vasorelaxing activity of chief constituents of Sunthi enhances drug acceptability in Pakshaghata.

\section{Shamana Chikitsa for Pakshaghata:}

* Ayurveda formulation such as; Rasnadi churna, Gandharvhastyadi kashayam, Baladi ghrita, Nirgundadi taila, Sahacharadi taila, Yogaraja Guggulu, Shwadanstra taila and Rasna taila may be used to normalize vitiated Vata Doshas.

* Tailas and ghrutas as pana \& abhyanga offer nourishment to body. Similarly Ekangveer Ras and Rajat Bhasma possess neurostimulant property.

* Mahamanjishtadi kashayam, Abhayaamalaki Rasayana and Kumariasavam offers vatashamana effect used to balances vitiated Vata Dosha associated with Pitta in Pakshaghata.

* Vitiated Vata Dosha associated with Kapha may be balanced by using formulation such as; Dashmoolarishta, Dashmooayam, Dashmooladi ghruta, Lavangarista, Chitrakadi ghruta and Rasna taila.

\section{Shodhana Chikitsa for Pakshaghata:}

Shodhana is purification process help to eliminate vitiated Doshas and Dushyas from body. Panchakarma is major approach of purification involving sub-therapies such as; Swedana, Snehana, Anuvasana Basti, Nasya, Shirobasti and Shirodhara etc. These therapies offer remarkable beneficial effects in Pakshaghata. Panchakarma lubricates body, reduces Rukshatva, empowered muscles, remove stiffness and improve muscle tone therefore Panchakarma possesses great symptomatic relief in Pakshaghata (8-12).

\section{PATHYA}

\section{Aahar:}

* Mash, Godhooma, Kulthi, Raktabha Shali and Navina Tila. 
* Draksha, Dadima, Amla Rasayukta Phala, Parushka, Badar, Jambira, Pakwa Tal, Rasala, Nagaranga and Tintindi Phala.

* Anupa, Gramya, Audak, Jangala Mamsa.

\section{Vihaara:}

Sukhoshna Parisheka, Abhyanga, Nirvata Sthana, Basti, Avgahana, Bhushaiya, Snan, Upanaha, Aasana, Shiro Basti, Shayanam, Nasya, Agni-Atapa Sewan, Samvahanam and Snigdha-Ushna Lepa.

\section{APATHYA}

Aahar:

Chanaka, Kathillaka, Rajmasha, Neevar, Kanguni, Bimbi, Nishpava Beeja, Kesheruk, Kordusha, Shyamak Churna, Mudga, Kuruvinda, Jambu, Kramuka, Mrunal, Trunaka, Talaphalasthimajja, Tinduka, Bala Tal, Shimbi, Patra Shaka, Shaluka, Shushka Mamsa and Dushita Jala.

\section{Vihaar:}

Vyavaya, Atibramana, Vegavidharana, Prajagarana, Chardi, Shrama, Rakta Mokshana, Chinta, Ati-Gaja, Anashana and Ashwa.

\section{Acknowledgement}

The authors are thankful to IJIST Journal for publishing their article.

\section{Conflicts of Interest}

The author declares that there are no conflicts of interest.

\section{References}

1. YT Acharya, Editor, Caraka, Carakasamhita Chikitsasthana 26/77-103 Choukhambha Krishnadas Academy, Reprint 2006. 602-605

2. YT Acharya Editor, Caraka, Carakasamhita Sutrasthana 26/4 Choukhambha Krishnadas Academy, Reprint 2006. 144.

3. Pandit Parasuram Sastri Editor, Sarngadhara, Sarngadharasamhita Pradhamakhanda 4/9-10 Choukhambha Surabharati Prakashan, Varanasi, 2006. 36-37.

4. K. Nishteswar, Ayurvedic Management of Stroke (Hemiplegia), Choukhambha Krishnadas Academy Varanasi, 2nd Edition, 2009. 61.

5. Dr. G.S Pandey Editor, Bhavamisra, Bhavaprakasanighantu, 1/196chowkambha Bharathi Academy, Varanasi, 2010. 111.

6. Harisastri Paradakar Editor, Vaghbata, Ashtangahridaya Uttarasthana 40/48, Choukhambha Krishnadas Academy, 2006. 943.
7. Sastry J.L.N., Illustrated Dravyaguna vijnana Vol II, 2ed, Varanasi, Published by Chaukhambha Orientalia, 2005, 276p

8. Kamanna VS, Chandrasekhara N. Hypocholesteremic activity of different fractions of garlic. Indian $\mathrm{J}$ Med Res. 1984; 79: 580.

9. Agnivesha, Charaka, Dridabala. Charaka Samhith, Sutrastana, Maharoga Adyaya, Chapter20, Verse11, Edited by Vaidya Yadavaji Trivikramaji Acharya. Chaukambha Prakashana, Varanasi 2013;P113

10. Munjal YP API Text book of medicine. Vol-2, 9th edition. New Delhi. Jaypee brothers Medical publishers(p) Ltd. 2012; P- 1401

11. Munjal YP API Text book of medicine.9thedition.Vol-2, Newdelhi. Jaypee brothers Medical publishers (p) Ltd. 2012; P 1403.

12. Vagbhatacharya, Astanga Hrudaya, Sutrastana, Doshopakramaniya adyaya. Chapter13, Verse23, Edited by Dr Anna Moreshvara Kunte and Dr Krishna shastrynavare, Choukhamba Samskruta Samsthana, Varanasi 2010;P 216 